\title{
Functional Expression and One-Step Protein Purification of Manganese Peroxidase 1 (rMnP1) from Phanerochaete chrysosporium Using the E. coli-Expression System
}

\author{
Angel De La Cruz Pech-Canul ${ }^{1}{ }^{\circledR}$, Javier Carrillo-Campos ${ }^{2}$, María de Lourdes Ballinas-Casarrubias ${ }^{2}$, \\ Rosa Lidia Solis-Oviedo ${ }^{3}{ }^{\circledR}$, Selena Karina Hernández-Rascón ${ }^{2}$, León Raúl Hernández-Ochoa ${ }^{2}$, \\ Néstor Gutiérrez-Méndez ${ }^{2}$ and Antonio García-Triana ${ }^{2, *(1)}$ \\ 1 CONACyT-Faculty of Chemical Sciences, Autonomous University of Chihuahua, Campus II, Chihuahua \\ 31125, Mexico; angelpechcanul@gmail.com \\ 2 Faculty of Chemical Sciences, Autonomous University of Chihuahua, Campus II, Chihuahua 31125, Mexico; \\ jc890917@hotmail.com (J.C.-C.); mballinas@uach.mx (M.d.L.B.-C.); a291849@uach.mx (S.K.H.-R.); \\ lhernandez@uach.mx (L.R.H.-O.); ngutierrez@uach.mx (N.G.-M.) \\ 3 Healthy Life Importadora, Exportadora Y Productora De Alimentos Y Bebidas, Sociedad De \\ Responsabilidad Limitada De Capital Variable, Chihuahua 31125, Mexico; solisoviedo@gmail.com \\ * Correspondence: atriana@uach.mx
}

Received: 3 December 2019; Accepted: 19 December 2019; Published: 9 January 2020

check for updates

\begin{abstract}
Manganese peroxidases $(\mathrm{MnP})$ from the white-rot fungi Phanerochaete chrysosporium catalyse the oxidation of $\mathrm{Mn}^{2+}$ to $\mathrm{Mn}^{3+}$, a strong oxidizer able to oxidize a wide variety of organic compounds. Different approaches have been used to unravel the enzymatic properties and potential applications of MnP. However, these efforts have been hampered by the limited production of native MnP by fungi. Heterologous expression of $\mathrm{MnP}$ has been achieved in both eukaryotic and prokaryotic expression systems, although with limited production and many disadvantages in the process. Here we described a novel molecular approach for the expression and purification of manganese peroxidase isoform 1 (MnP1) from P. chrysosporium using an E. coli-expression system. The proposed strategy involved the codon optimization and chemical synthesis of the MnP1 gene for optimised expression in the E. coli T7 shuffle host. Recombinant MnP1 (rMnP1) was expressed as a fusion protein, which was recovered from solubilised inclusion bodies. $\mathrm{rMnP} 1$ was purified from the fusion protein using intein-based protein purification techniques and a one-step affinity chromatography. The designated strategy allowed production of an active enzyme able to oxidize guaiacol or $\mathrm{Mn}^{2+}$.
\end{abstract}

Keywords: manganese peroxidase; $\mathrm{MnP1}$; recombinant; codon-optimization; Phanerochaete; Escherichia coli; inteins; chitin binding domain (CBD); protein purification; affinity chromatography

\section{Introduction}

Manganese peroxidases (MnP, E.C.1.11.1.13) were first described as a part of the lignin degrading system from the white-rot fungi Phanerochaete chrysosporium [1]. These enzymes have a heme prosthetic group, are $\mathrm{H}_{2} \mathrm{O}_{2}$ dependent, and catalyse the oxidation of $\mathrm{Mn}^{2+}$ to $\mathrm{Mn}^{3+}$ [2-4]. All known white-rot fungi produce $\mathrm{MnP}$ enzymes, enabling their capacity to degrade lignin. Indeed, it is due to this enzyme that fungi are the best known microorganism for degrading lignin polymer [5]. Lignin is an abundant biopolymer that plays a key role in supporting the growth of large and tall vascular plants. Its structure is a three-dimensional polymer network connected by several acid-resistant C-C linkages, consequently it is only partly degraded to monomeric compounds by hydrolysis but mostly 
degraded by oxidation [6]. The MnP catalytic cycle involves the cleavage of a molecule of $\mathrm{H}_{2} \mathrm{O}_{2}$ with the subsequent oxidation of the heme group in the enzyme structure. Then, $\mathrm{Mn}^{2+}$ is oxidized to $\mathrm{Mn}^{3+}$, a strong oxidizer which has to be stabilized by organic acids such as oxalate [7]. The $\mathrm{Mn}^{3+}$-organic acid complex formed during the reaction acts as a diffusible oxidant able to oxidize lignin and several xenobiotic compounds.

$\mathrm{MnP}$ has been broadly researched due to its enzymatic properties and its potential industrial applications. However, its extensive use is mainly hampered by two main intrinsic properties: the limited production of the enzyme by P. chrysosporium and its low stability [8]. Different approaches have been explored in order to optimize its enzymatic properties, for example site-directed mutagenesis was performed to obtain mutated versions of $\mathrm{MnP}$ that are more resistant to $\mathrm{H}_{2} \mathrm{O}_{2}$ [9], or less susceptible to elevated temperatures and/or $\mathrm{pH}$ [10]. On the other hand, several modifications of the growth conditions and culture media composition have been explored in order to improve the amount of enzymes produced by fungi. Such modifications included the immobilization of fungal cells [11], incubation at different ranges of temperature or $\mathrm{pH}$, addition of Tween 80 or cofactors to the culture media, nitrogen limitation, growth on solid media instead of liquid cultures [12-15], and so on. Moreover, heterologous expression of MnP has been achieved in Escherichia coli [16-18], using the baculovirus expression system [19], in Pichia pastoris [20-24], in Aspergillus [8,25,26], and in a cell free system $[27,28]$.

In the present work, a novel molecular approach was used to obtain a functional recombinant MnP1 (rMnP1) from P. chrysosporium. The MNP1 gene was codon-optimized and chemically synthesized for its heterologous expression in the E. coli expression system. Currently, this expression system represents a fast, efficient, and cheap strategy to express and recover proteins from either eukaryotic or prokaryotic sources. Recombinant protein was purified using an intein (INTervening protEINs) self-cleavage system. This self-splicing system negates the need for adding protease to catalyse release of the protein of interest [29]. For nearly two decades, these systems have shown their effectiveness as a quick method of purification with considerable yields of purified recombinant proteins [30-32]. To the best of the authors' knowledge, the use of a synthetic, codon-optimized MnP1 gene combined with its heterologous expression in an E. coli host and intein-based protein purification techniques to achieve a purified $\mathrm{rMnP1}$ has not been previously reported elsewhere.

\section{Results}

\subsection{Construction of Recombinant Expression Vector pTXB1-MnP1}

Synthetic MnP1 gene was cloned into the pTXB1 vector using NdeI/SapI restriction sites and delivered into Escherichia coli DH5 $\alpha$ cells. Construct, termed pTXB1-MnP1, contains a fusion between the $\mathrm{C}$-terminus of $\mathrm{rMnP1}$ and the intein tag, which conveniently contains a chitin binding domain (CBD) for the affinity purification of the fusion protein on a chitin resin column. The overall process for the construction of pTXB1-MnP1 is summarized in the diagram depicted in Figure 1. Transformed clones were confirmed by colony PCR (Figure 2) with an expected band of $1100 \mathrm{bp}$. The correct nucleotide sequence of synthetic MnP1 gene was further confirmed by DNA sequencing. The coding sequence of the synthetic MnP1 gene was codon-optimized for better expression in E. coli. Its sequence encodes for a protein of 356 amino acids which is identical to isoform 1 of $\mathrm{MnP}$ from Phanerochaete chrysosporium. 


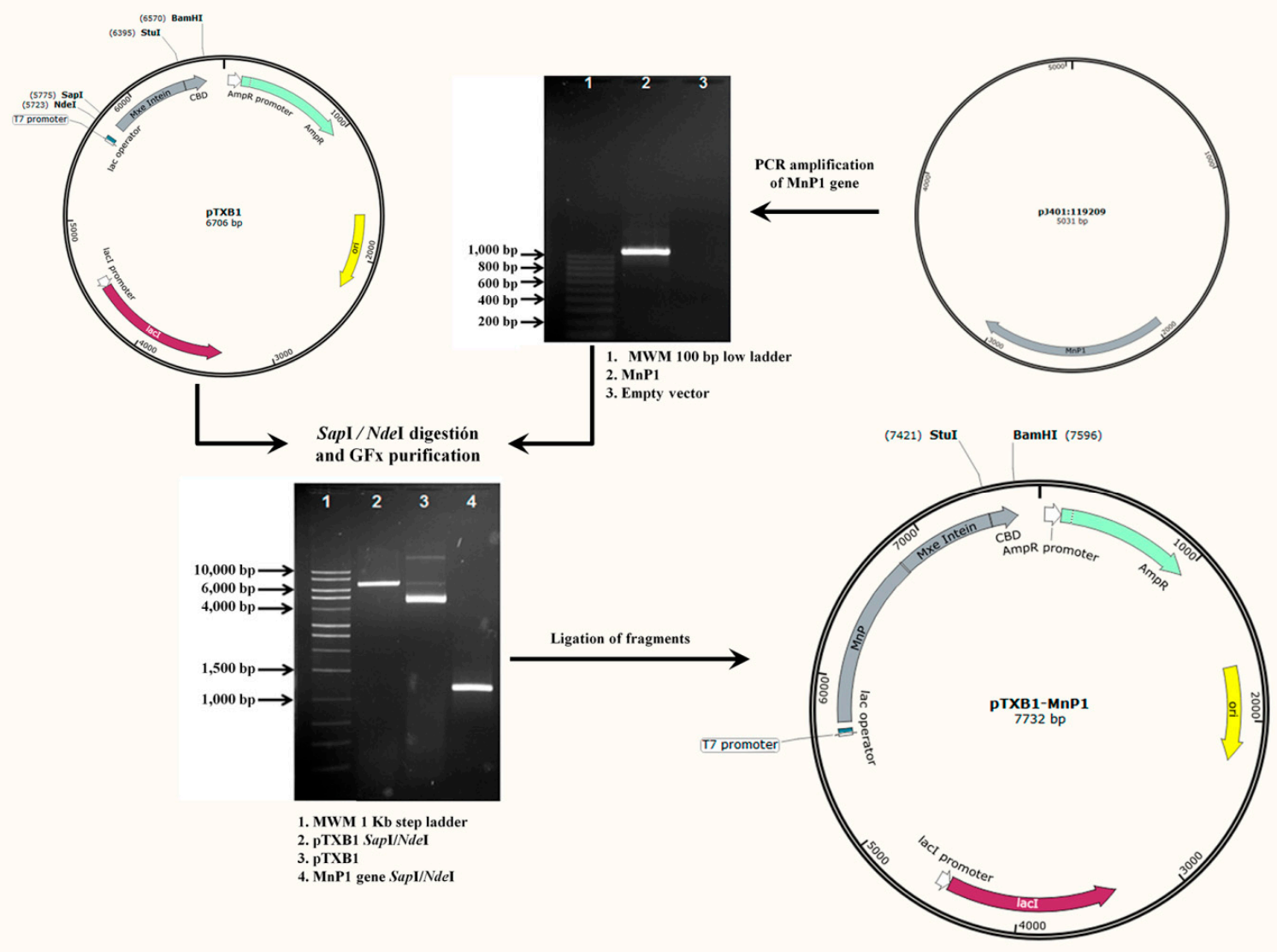

Figure 1. Schematic representation for the construction of the recombinant plasmid pTXB1-MnP1.

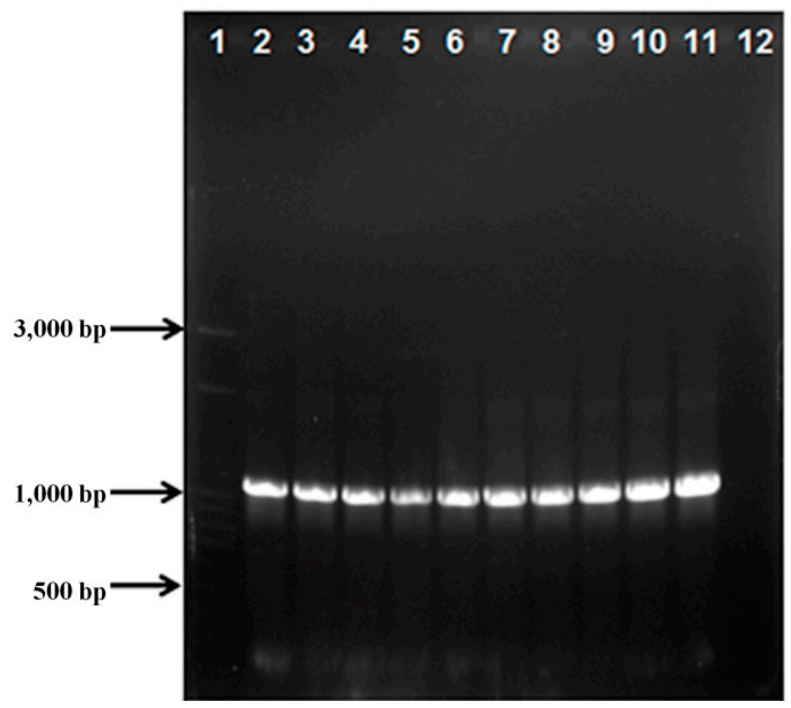

Figure 2. Colony PCR for pTXB1-MnP1 candidates. 1. MWM 50 bp step ladder; $2-11$. Candidates; 12.

Empty vector.

\subsection{Expression of Fusion Protein $r M n P 1-I n t e i n-C B D$}

The construct pTXB1-MnP1 was used to transform E. coli T7 shuffle competent cells. This engineered strain constitutively expresses the disulfide bond isomerase (DsbC) which promotes disulfide bond formation in the cytoplasm. Additionally, DsbC promotes the correction of miss-oxidized proteins into their correct form by serving as a folding chaperone for proteins that do not require 
disulfide bonds. The expression of fusion protein rMnP1-intein-CBD and its solubilisation were tested with three different IPTG concentrations $(0.1,0.4$, and $0.8 \mathrm{mM})$ at $37^{\circ} \mathrm{C}$ for $12 \mathrm{~h}$. After induction, cells were collected by centrifugation and suspended in lysis buffer. Sonication alternated with cooling in ice water was applied to the samples in order to enhance solubilisation. The cell-lysate was centrifuged at $15,000 \times g$ for $15 \mathrm{~min}$ at $4{ }^{\circ} \mathrm{C}$. Soluble and insoluble fractions were both analysed by SDS-PAGE (Figure 3). Fusion protein $(\sim 66.5 \mathrm{kDa})$ was negligible in the soluble fractions of the three different conditions tested for induction. On the other hand, all insoluble fractions had an intense signal at the expected size of the fusion protein. This suggested that the protein fusion was stored in inclusion bodies, in a similar way as previously reported for other manganese peroxidases [16,17].

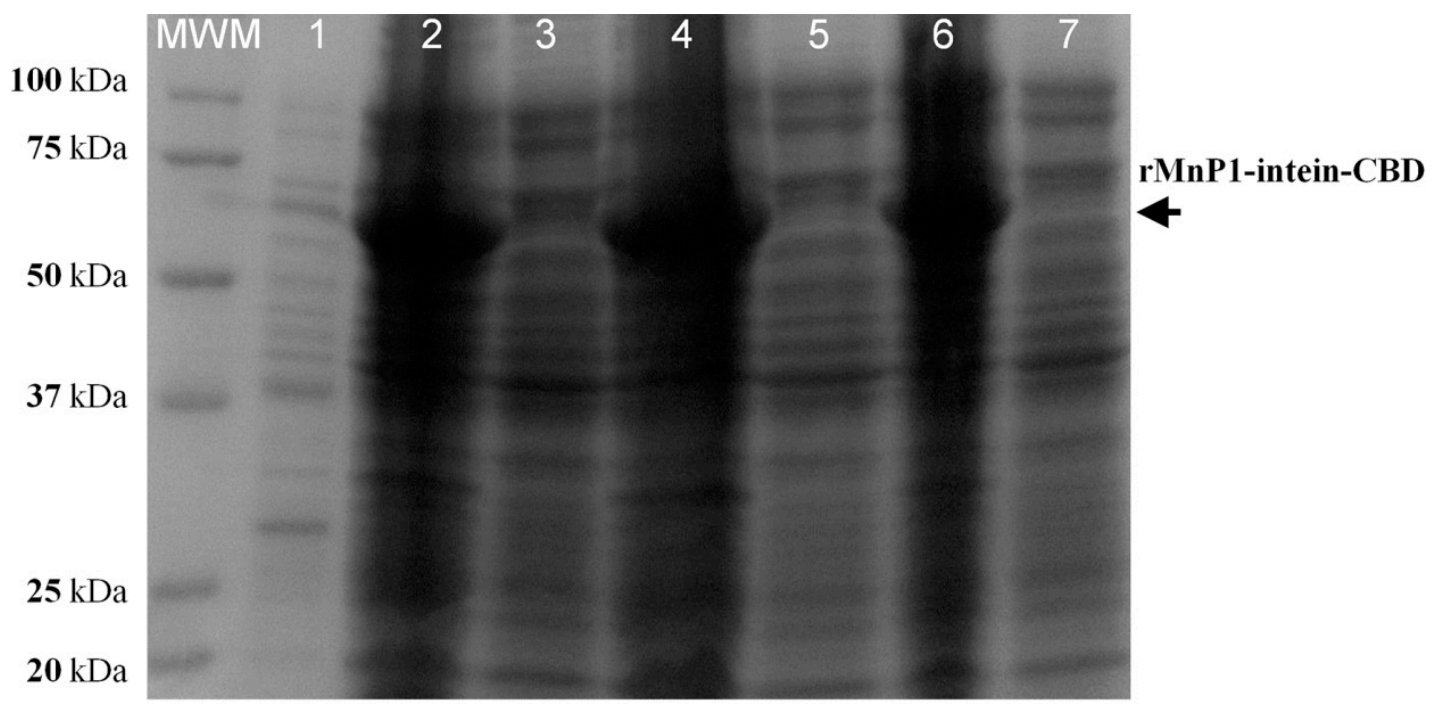

Figure 3. SDS-PAGE with uninduced and isopropyl- $\beta-D$ thiogalactopyranoside (IPTG)-induced cells of E. coli $\mathrm{T} 7$ shuffle expressing the protein fusion $\mathrm{rMnP1}$-Intein-CBD. When cultures reached an $\mathrm{OD}_{600 \mathrm{~nm}}$ of 0.5 , they were induced with different concentrations of IPTG and incubated at $37^{\circ} \mathrm{C}$ for $12 \mathrm{~h}$ : induction with $0.1 \mathrm{mM}$ IPTG, insoluble (lane 2) and soluble (lane 3) fractions; induction with $0.4 \mathrm{~m}$ M IPTG, insoluble (lane 4) and soluble (lane 5) fractions; induction with $0.8 \mathrm{mM}$ IPTG, insoluble (lane 6) and soluble (lane 7) fractions. Lane 1: Uninduced with IPTG. MWM: Kaleidoscope Protein Standard.

The protein expression was attempted to optimize with a fixed concentration of $0.1 \mathrm{mM}$ IPTG. Assays to improve expression levels were conducted by lowering the incubation temperature or by varying induction time. However, the expression of the fusion protein was negatively affected by tested conditions [33]. Therefore, conditions for expression of fusion protein were fixed to induction with $0.1 \mathrm{mM}$ IPTG at $37^{\circ} \mathrm{C}$ for $12 \mathrm{~h}$.

\subsection{Solubilisation and Purification of $r M n P 1$}

For the solubilisation of proteins from inclusion bodies, different concentrations of urea $(0.5,1$, 2,4 , or $8 \mathrm{M}$ ) were tested in the denaturing buffer $(20 \mathrm{mM}$ Tris- $\mathrm{HCl} \mathrm{pH} \mathrm{8.5;} 500 \mathrm{mM} \mathrm{NaCl} ; 1 \mathrm{mM}$ EDTA). The solubilisate was incubated in ice for six $h$ and further analysed by SDS-PAGE. The presence of the fusion protein in soluble form was confirmed, however, no obvious spot differences were observed between 4 or $8 \mathrm{M}$ urea treatments (Figure 4). Concentrations below $4 \mathrm{M}$ urea were also tested; however, these conditions failed to solubilisate inclusion bodies [33]. Thus, solubilisation for protein purification was conducted with $4 \mathrm{M}$, in order to diminish urea-induced changes that may affect protein rMnP1 structure.

Solubilisate extract containing fusion protein was applied to a chitin bead column at a flow rate of $0.5 \mathrm{~mL} \mathrm{~min}^{-1}$. The fusion protein $\mathrm{rMnP1}$-intein-CBD was efficiently bound to the chitin column due to the chitin binding domain (Figure 5, lane 4 ). The column was washed with 45 column volumes 
(cvs) of column buffer to remove unretained proteins (Figure 5, lane 5), and self-cleavage of the fusion protein was induced with $3 \mathrm{cvs}$ of cleavage buffer. After premature cleavage of the fusion protein was discarded (Figure 5, lane 6), the column was sealed and incubated at room temperature for $36 \mathrm{~h}$ in order to promote self-cleavage of the fusion protein and the subsequent refolding of rMnP1. Ten cvs of column buffer were used to elute rMnP1 from the column, and each fraction (equivalent to one cv) was separately collected. The highest signal for $\mathrm{rMnP1}$ was seen in the first 1-3 fractions (Figure 5, lane 7 and 8). Furthermore, rMnP1 was negligible after the elution process (Figure 5, lane 9).

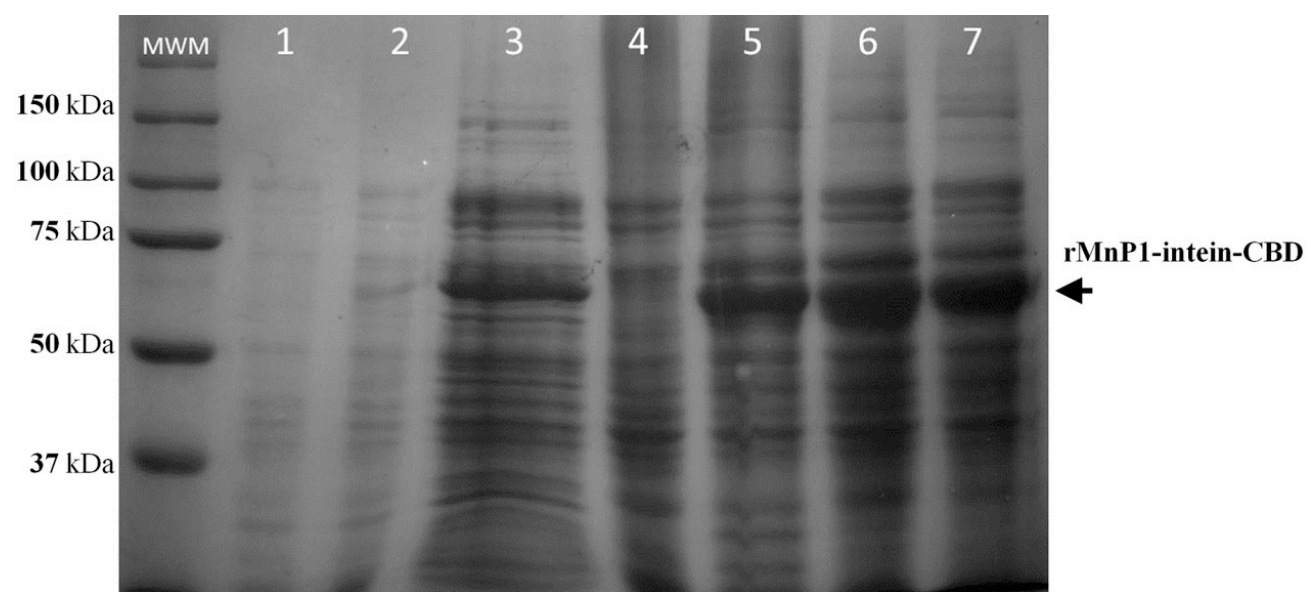

Figure 4. Solubilisation of MnP1-Intein-CBD fusion from inclusion bodies. SDS-PAGE analysis of the insoluble fraction treated with buffer containing 4 or $8 \mathrm{M}$ urea. When cultures reached an $\mathrm{OD}_{600 \mathrm{~nm}}$ of 0.5 , they were induced with $0.1 \mathrm{mM}$ of IPTG and incubated at $37^{\circ} \mathrm{C}$ for $12 \mathrm{~h}$. Lane 1: Uninduced cells. Lane 2: Induced cells. Lane 3: Whole cell lysate. Lanes 4 and 5 correspond to soluble fraction and inclusion bodies, respectively. Inclusion bodies were treated with $4 \mathrm{M}$ or $8 \mathrm{M}$ urea (Lane 6 and 7, respectively). MWM: Kaleidoscope Protein Standard.

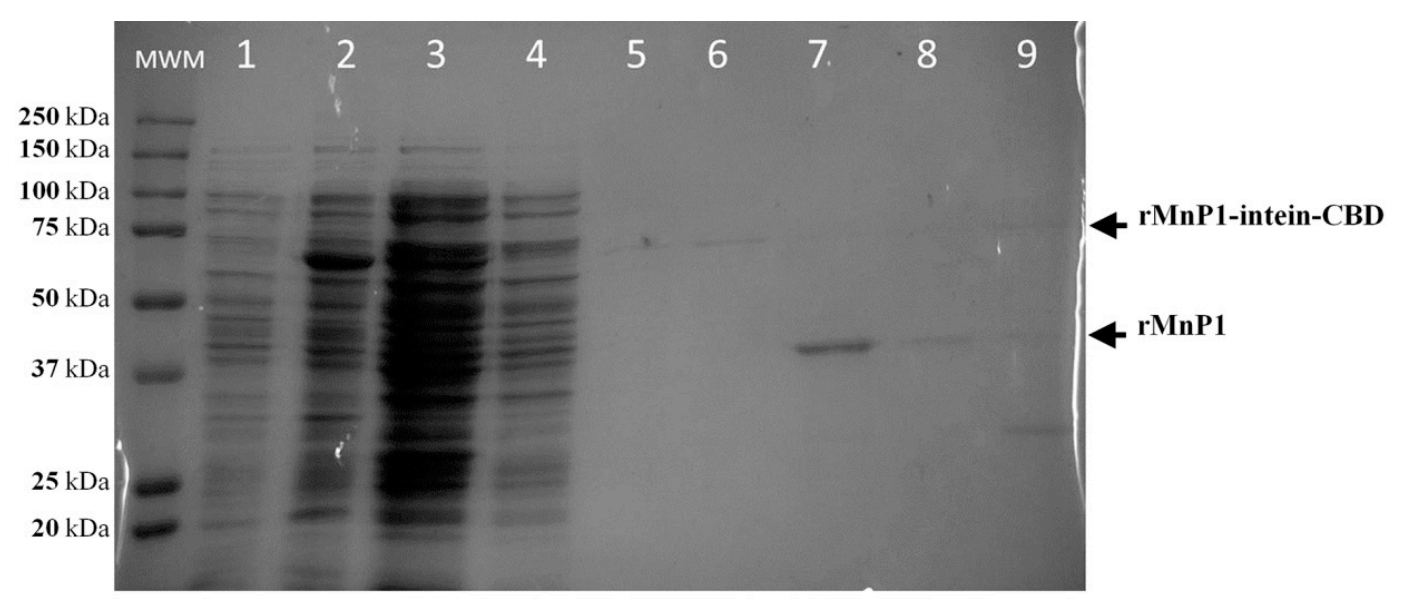

Figure 5. Purification of rMnP1. SDS-PAGE analysis for the purification of rMnP1 by one-step affinity chromatography. When cultures reached an $\mathrm{OD}_{600 \mathrm{~nm}}$ of 0.5 , they were induced with $0.1 \mathrm{mM}$ of IPTG and incubated at $37^{\circ} \mathrm{C}$ for $12 \mathrm{~h}$. Inclusion bodies, containing fusion protein rMnP1-intein-CBD, were solubilised with $4 \mathrm{M}$ urea. Lane 1: Uninduced cells. Lane 2: Induced cells. Lane 3: Inclusion bodies treated with $4 \mathrm{M}$ urea. Lane 4: Chitin column flow-through containing unretained proteins. Flow-through after washing with column buffer (Lane 5) and after treating with cleavage buffer (Lane 6). Lanes 7-8: Fractions containing rMnP1. Lane 9: Flow-through after the elution process. MWM: Kaleidoscope Protein Standard. 


\subsection{Quantification and Protein Sequencing of $r M n P 1$}

Prior to quantification, DTT was removed from the sample during protein concentration in a Pierce Protein Concentrator PES, 30K MWCO (Thermo Scientific). The strategy followed in the present work allowed the production of $\sim 25 \mathrm{mg}$ of $\mathrm{rMnP} 1$ per each litre of IPTG-induced culture. In order to confirm the correct sequence of $\mathrm{rMnP1}$, protein sequencing was accomplished through digestion of rMnP with trypsin and subsequent analysis of digested fragments by MALDI-TOF/TOF. The results confirm the designed amino-acid sequence of $\mathrm{rMnP1}$, which is the same amino-acid sequence as the isoform 1 (MnP1) of P. chrysosporium (Accession number: Q02567. UniProtKB/Swiss database).

\subsection{Enzyme Activity}

In order to confirm the rMnP1 activity, standard assays previously reported for manganese peroxidases were carried out. The Varioskan Flash plate reader was used for measuring optical density. The machine is equipped with an automated dispensing unit, which has the advantage of accurately measuring the start point of each assay. The assays showed no changes in absorbance at the recommended final enzyme concentration $[1,34]$. It was found that enzyme activities for the oxidation of guaiacol were consistent with 2.8 or $1.4 \mu \mathrm{g} \mathrm{mL}^{-1}$ of rMnP1 (Figure 6A). The enzyme activity for these concentrations were 0.555 and $0.255 \mathrm{U} \mathrm{L}^{-1}$; with a similar specific activity of 0.196 and $0.179 \mathrm{U}$ $\mathrm{mg}^{-1}$, respectively. Complementarily, assays for the oxidation of $\mathrm{Mn}^{2+}$ were also carried out in order to verify the capability of rMnP1 to oxidize $\mathrm{Mn}^{+2}$. These assays also confirmed the activity of rMnP1 (Enzyme activity $166.3 \mathrm{U} \mathrm{L}^{-1}$, specific activity $58.8 \mathrm{U} \mathrm{mg}^{-1}$ ) (Figure 6B).

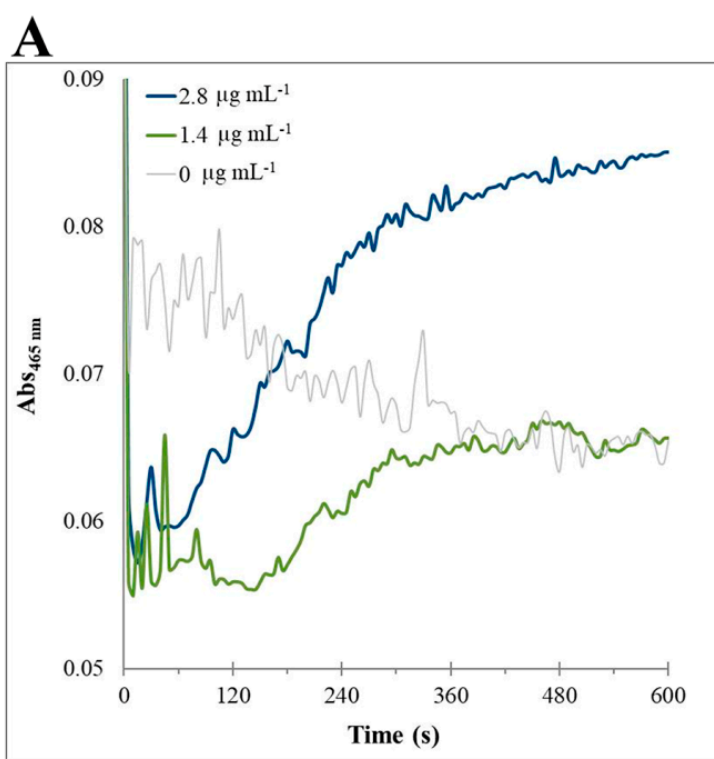

B

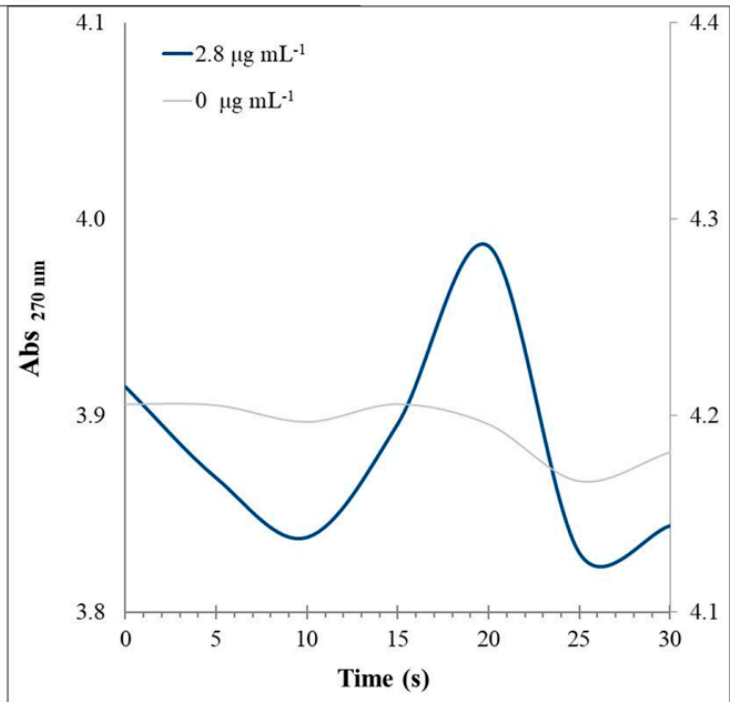

Figure 6. Standard assays for manganese peroxidases. Oxidation of guaiacol and oxidation of $\mathrm{Mn}^{+2}$ assays were both measured by spectrophotometry. In (A), the oxidation of guaiacol was measured as the change in absorbance at $465 \mathrm{~nm}$. Reaction mixture contains rMnP1 (2.8 or $\left.1.4 \mu \mathrm{g} \mathrm{mL}^{-1}\right)$, sodium succinate (500 mM, pH 4.5), guaiacol (100 mM), and $\mathrm{MnSO}_{4}(50 \mathrm{mM})$. Reactions were initiated by addition of $\mathrm{H}_{2} \mathrm{O}_{2}(10 \mathrm{mM})$. For the oxidation of $\mathrm{Mn}^{2+}$ assays $(\mathbf{B})$ the oxidation of $\mathrm{Mn}^{2+}$ to $\mathrm{Mn}^{3+}$ was followed by measuring the absorbance change at $270 \mathrm{~nm}$. The reaction mixture comprises of $\mathrm{rMnP} 1$ enzyme $\left(2.8 \mu \mathrm{g} \mathrm{mL}^{-1}\right)$, sodium malonate $(50 \mathrm{mM}, \mathrm{pH} 4.5)$, and $\mathrm{MnSO}_{4}(100 \mathrm{mM})$. Reactions were initiated by addition of $\mathrm{H}_{2} \mathrm{O}_{2}(100 \mathrm{mM})$. The final volume of each reaction mix was $200 \mu \mathrm{L}$. The enzyme was omitted $\left(0 \mu \mathrm{g} \mathrm{mL}^{-1}\right)$ in the reference assays. Plots are representative from each of the triplicate sets. 


\section{Discussion}

Manganese peroxidases have been extensively studied for more than a decade with many works focused on elucidating their enzymatic mechanisms [1,2,4,34]. Additionally, studies also reported the wide diversity of potential industrial applications they have $[8,15,21]$. The potential versatility of manganese peroxidases is probably the result of (1) a very high redox potential when compared to other peroxidases, and (2) the produced $\mathrm{Mn}^{3+}$-oxidant being able to oxidize several types of organic molecules [4]. Many efforts have been made towards improving the production of native $\mathrm{MnP}$ by fungi but have been met with limited success, hindering their widespread industrial use [11-13]. However, strategies for the overexpression and purification of $\mathrm{MnP}$ were accomplished in eukaryotic expression systems [19-22] and in the prokaryotic expression system of Escherichia coli [16,17,35]. In these studies, the authors overcame many hurdles, such as the potential contamination with other $\mathrm{MnP}$ and LiP isozymes or the formation of inclusion bodies that require further treatments to obtain an active enzyme.

In the present work we accomplished the expression of a functional rMnP1 by using a novel approach. In order to increase the quantity of expressing protein we first designed a synthetic MNP1 gene, which was codon-optimized for its best expression in Escherichia coli. Then, we created a fusion protein based on the intein-mediated purification system. The pTXB1 vector promotes the expression of a fusion protein $\mathrm{rMnP1}$-intein-CBD, where the chitin binding domain (CBD) allowed the efficient purification of rMnP1 by a single-step affinity chromatography. Conveniently, the expression host, E. coli $\mathrm{T} 7$ shuffle, constitutively expresses the disulfide bond isomerase (DsbC), which has been proven to positively impact the production of recombinant MnP [28]. Additionally, the cleavage buffer contains dithiothreitol (DTT), which promotes the self-excision of the target protein. DDT is regularly used to reduce or to prevent the intermolecular interaction forming among cysteine residues of proteins. With this approach, we produced $25 \mathrm{mg}$ of purified $\mathrm{rMnP1}$ from $\mathrm{L}^{-1}$ of induced culture. The amount of purified rMnP1 was remarkably higher than previous report for E. coli (275 $\mu \mathrm{g} \mathrm{L}^{-1}$ in [17]) or even for some reports in eukaryotic expression systems ( $550 \mu \mathrm{g} \mathrm{L}^{-1}$ in [23], $5 \mathrm{mg} \mathrm{L}^{-1}$ in [25]). Conversely, Conesa and coworkers [36] reported a higher production of recombinant MnP1 in Aspergillius niger by adding hemin or haemoglobin to the culture medium, yielding $\sim 66 \mathrm{mg} \mathrm{L}^{-1}$ and $\sim 100 \mathrm{mg} \mathrm{L}^{-1}$, respectively. Similar results were also reported in Pichia pastoris $\left(\sim 148 \mathrm{mg} \mathrm{L}^{-1}\right)$ [24] and in A. niger (no yield reported) [26]. However, these studies involved the use of expensive heme additives for the production of a functional enzyme. Finally, the enzyme activity of the purified rMnP1 was confirmed by standard assays. The purified $\mathrm{rMnP} 1$ is able to oxidize guaiacol using a previously reported protocol for native $\mathrm{MnP}$ [1-3]. The assays were reproducible with an enzyme activity nearly proportional to the amount of $\mathrm{rMnP} 1$ added to the reaction (Figure 6A). Additionally, their specific activity values were comparable in agreement with a pure enzyme preparation. Complementarily, the capability of rMnP1 to oxidize $\mathrm{Mn}^{2+}$ was also verified. This assay is recommended for purified enzymes, which have less contaminant metals, such as $\mathrm{Fe}$ or $\mathrm{Cu}$, present in crude preparations that inhibit activity. The progress of the reaction is consistently measured during the first 30-s (Figure 6B), as reported previously [37].

Other experimental approaches were attempted in order to optimize our strategy. For example, the expression of the fusion protein $\mathrm{rMnP1}$-intein-CBD, under the control of T7 promoter, caused the formation of inclusion bodies, a drawback we tried to overcome by lowering expression levels with no remarkable results [33]. The incorporation of physical disruption methods, such as sonication and vortex, was insufficient to disaggregate inclusion bodies; consequently, the solubilisation of inclusion bodies was achieved with $4 \mathrm{M}$ urea (Figure 5). Another point to consider is the proper refolding of MnP after recovering from inclusion bodies $[16,17,28,35]$. Currently there is no single method of refolding that fits for all proteins. The refolding of recombinant protein from bacterial inclusion bodies is still a challenge for the correct expression of proteins from any source. In this work, we did not include any additional steps for the in vitro refolding of rMnP1. It is likely that both the constitutive expression of DsbC by the E. coli host and the presence of DDT during the self-cleavage step promote the refolding of $\mathrm{MnP1}$, since the purified enzyme was active. Hence, our strategy can be refined if 
combined with other improvements. For example, the production of a recombinant $\mathrm{MnP}$ in E. coli was favoured by the presence of calcium and hemin during in vitro refolding, generating an active enzyme with similar properties to those of the native MnP $[17,28]$. Furthermore, a recent work presented a strategy where the co-expression of a combination of chaperones, alongside the expression of DsbC, allowed production of a soluble form of recombinant $\mathrm{MnP}$ in E. coli. However, the recombinant MnP produced still had to be subject to in vitro maturation using hemin, ATP, and an ATP regeneration system in order to help chaperones to finish their folding cycle [35]. Another strategy that could be addressed is by simultaneously decreasing the temperature of expression $\left(16^{\circ} \mathrm{C}\right)$ and supplementing the culture medium with four chemical additives (Triton X-100, Tween-80, glycerol, and ethanol). This approach led to the production of a soluble, active form of MnP from Irpex lacteus using the E. coli expression system, which also prevented the formation of inclusion bodies [18]. Overall, the E. coli expression system has proven to be a promising alternative to the eukaryotic expression system for the expression of $\mathrm{MnP}$, resulting in higher yields of active enzyme in fewer steps.

\section{Materials and Methods}

\subsection{Synthetic MnP1 Gene}

A search in the UniProtKB/Swiss database was performed to screen for MnP genes from Phanerochaete chrysosporium. At least four isoforms of the MnP gene were identified. Due to the complete information available for both gene and protein, the isoform 1 (MnP1, Accession number: Q02567) was chosen. The nucleotide sequence of cDNA encoding MnP1 was used to design a synthetic gene. The synthetic MnP1 gene was codon-optimized and chemically synthesized by DNA 2.0 (Newark, CA, USA). Codon optimization was performed with the GeneGPS ${ }^{\mathrm{TM}}$ program (DNA 2.0) using algorithms for high expression in Escherichia coli. The signal peptide (21-amino acids leader sequence) was excluded from the nucleotide sequence. For cloning into the expression vector, recognition sites for endonucleases NdeI and SapI were incorporated in the $5^{\prime}$ and $3^{\prime}$ ends of the synthetic sequence, respectively.

\subsection{Strains, Vector, Chemicals, Media, Culture Conditions}

E. coli DH5 $\alpha$ strain (Invitrogen, Carlsbad, CA, USA) was used as the host strain for cloning and maintaining plasmids, whereas E. coli T7 shuffle strain (New England Biolabs, NEB) was used as the host for protein expression. Strains were cultured in Luria broth (LB) from Sigma. Liquid cultures were routinely incubated at $37^{\circ} \mathrm{C}$ and $150 \mathrm{rpm}$. Culture media were supplemented with ampicillin $\left(100 \mu \mathrm{g} \mathrm{ml}^{-1}\right)$. Enzymes, expression vector pTXB1, and chitin resin were all included in the commercial IMPACT Kit (NEB). Primers were synthesized by Integrated DNA Technologies (IDT). Other reagents used in experimental procedures were purchased from Sigma.

\subsection{PCR Conditions, Cloning, Transformation, and DNA Sequencing}

The synthetic MNP1 gene was delivered cloned in pJ401:119209 (DNA 2.0). The synthetic gene was amplified from pJ401:119209 by PCR using Amplitaq Gold 360 Master Mix (Applied Biosystems) with specific primers F1: 5' - GGTGGTCATATGGCAGTTTGTCCGGATG-3' and R1: 5' GGTGGTTGCTCTTCCGCACGCCGGACCATTGAAT-3'. The incorporated NdeI and SapI restriction sites, respectively, are underlined. Amplification was performed on a Bio-Rad thermal cycler (Bio-Rad, model: T100) with $10 \mathrm{~min}$ at $94{ }^{\circ} \mathrm{C}$ for the initial denaturation step followed by 35 cycles of $1 \mathrm{~min}$ at $94{ }^{\circ} \mathrm{C}, 1 \mathrm{~min}$ at $68^{\circ} \mathrm{C}, 1.5 \mathrm{~min}$ at $72^{\circ} \mathrm{C}$ for extension with a final extension of $7 \mathrm{~min}$ at $72{ }^{\circ} \mathrm{C}$. Purified PCR product and pTXB1 vector (IMPACT Kit, NEB) were both digested with NdeI and SapI. Digested fragments were purified with Illustra GFX (General Electric) and ligated with the T4 DNA ligase (PROMEGA). The ligation mix was used to transform competent cells of E. coli T7 shuffle. The construct pTXB1-MnP1, harbouring synthetic MNP1 gene was screened by colony PCR and its sequence was verified by commercial DNA sequencing (MACROGEN). 


\subsection{Expression of Fusion Protein rMnP1-Intein-CBD in E. coli}

For expression of the fusion protein consisting of recombinant $\mathrm{MnP1}(\mathrm{rMnP} 1)$, intein, and a chitin binding domain (rMnP1-intein-CBD), five $\mathrm{mL}$ of $\mathrm{LB}$, supplemented with $100 \mu \mathrm{g} \mathrm{mL} \mathrm{m}^{-1}$ of ampicillin $\left(\mathrm{LB}_{\mathrm{amp}}\right)$, was inoculated with single colonies of E. coli T7 shuffle pTXB1-MnP1 and incubated overnight. Then, $25 \mathrm{~mL}$ of $\mathrm{LB}_{\mathrm{amp}}$ was inoculated with $2 \mathrm{~mL}$ of the overnight culture and incubated until the $\mathrm{OD}_{600 \mathrm{~nm}}$ reached 0.5. One litre of $\mathrm{LB}_{\mathrm{amp}}$ was inoculated with the whole 25-mL culture and incubated until $\mathrm{OD}_{600 \mathrm{~nm}}$ again reached 0.5. Next, protein expression was induced with the addition of $0.1 \mathrm{mM}$ isopropyl- $\beta$-D thiogalactopyranoside (IPTG) and incubated for $12 \mathrm{~h}$. Induction was tested with 0.4 or $0.8 \mathrm{mM}$ IPTG added after 4,8 , or $24 \mathrm{~h}$ of incubation time. Cells were harvested by centrifugation at $3000 \times g$ at $4{ }^{\circ} \mathrm{C}$ for $30 \mathrm{~min}$. About $6 \mathrm{~g}$ of wet cell pellet was recovered from $1 \mathrm{~L}$ of culture. From there, $1.7 \mathrm{~g}$ of pellet was re-suspended in $15 \mathrm{~mL}$ of lysis buffer $(20 \mathrm{mM}$ Tris- $\mathrm{HCl} \mathrm{pH} \mathrm{8.5;} 500 \mathrm{mM} \mathrm{NaCl}$; $1 \mathrm{mM}$ EDTA; $0.1 \% v / v$ Triton X-100; $20 \mu \mathrm{M}$ PMSF) and sonicated on ice. The lysate was centrifuged at $15,000 \times \mathrm{g}$ for $30 \mathrm{~min}$ at $4{ }^{\circ} \mathrm{C}$. Both soluble and insoluble fractions were analysed by SDS-PAGE.

\subsection{Solubilisation of Fusion Protein rMnP1-Intein-CBD from Inclusion Bodies}

The insoluble fraction (about $1 \mathrm{~g}$ ) was resuspended in $5 \mathrm{~mL}$ of cold denaturation buffer $(20 \mathrm{mM}$ Tris- $\mathrm{HCl} \mathrm{pH} 8.5 ; 500 \mathrm{mM} \mathrm{NaCl} ; 1 \mathrm{mM}$ EDTA) containing different concentrations of urea $(0.5,1,2,4$, or $8 \mathrm{M}$ ) and incubated on ice for $5 \mathrm{~h}$. The mixture was centrifuged at $12,000 \times g$ for $15 \mathrm{~min}$ at $4{ }^{\circ} \mathrm{C}$. The resulting pellet was re-suspended in deionized water. Supernatant and resuspended pellet from the treated insoluble fraction were both analysed by SDS-PAGE in order to confirm the presence of a soluble form of the fusion protein.

\subsection{Purification of rMnP1 by One-Step Affinity Chromatography and Intein Self-Cleavage}

A column volume of $4 \mathrm{~mL}$ of chitin beads was equilibrated with column buffer $(20 \mathrm{mM}$ Tris- $\mathrm{HCl}$ $\mathrm{pH} 8.5 ; 500 \mathrm{mM} \mathrm{NaCl} ; 1 \mathrm{mM}$ EDTA; $4 \mathrm{M}$ Urea). Supernatant containing the soluble form of the fusion protein was passed through the column at a flow rate of $0.5 \mathrm{~mL} \mathrm{~min}{ }^{-1}$. Unbounded proteins were washed with 45 column volumes (cvs) of column buffer, followed by $3 \mathrm{cvs}$ of cleavage buffer $(20 \mathrm{mM}$ Tris- $\mathrm{HCl} \mathrm{pH}$ 8.5, $500 \mathrm{mM} \mathrm{NaCl}, 1 \mathrm{mM}$ EDTA, $50 \mathrm{mM}$ dithiothreitol (DTT)). Then, the column was sealed and incubated for $36 \mathrm{~h}$ at room temperature. $\mathrm{rMnP1}$ was eluted from the column with $10 \mathrm{cvs}$ of column buffer without urea, fractions of one column volume were collected separately.

\subsection{Quantification and Protein Sequencing of $r M n P 1$}

Protein concentration was determined by the Bradford assay using serum albumin as standard. Prior to quantification, DTT was removed from the eluted fractions while rMnP1 was concentrated in a Pierce Protein Concentrator PES, 30K MWCO (Thermo Scientific). The correct amino acid sequence of rMnP1 was verified by mass spectrometry using MALDI-TOF/TOF carried in an AutoFlexSpeedTM TOF/TOF Burker spectrophotometer.

\subsection{Enzyme Assays}

Oxidation of guaiacol and oxidation of $\mathrm{Mn}^{2+}$ assays were both performed and measured by spectrophotometry as described previously $[1-3,37]$. Briefly, the oxidation of guaiacol was measured as the change in absorbance followed by the tetraguaiacol formation. The reaction mixture in a total volume of $200 \mu \mathrm{L}$ contained rMnP1 enzyme, sodium succinate (500 mM, pH 4.5), guaiacol $(100 \mathrm{mM})$, and $\mathrm{MnSO}_{4}(50 \mathrm{mM})$. Reactions were initiated by the addition of $\mathrm{H}_{2} \mathrm{O}_{2}(10 \mathrm{mM})$. The increase in absorbance at $465 \mathrm{~nm}$ was recorded at 5-s intervals for $10 \mathrm{~min}$.

For the oxidation of $\mathrm{Mn}^{2+}$ assays, the oxidation of $\mathrm{Mn}^{2+}$ to $\mathrm{Mn}^{3+}$ was determined by measuring the absorbance change at $270 \mathrm{~nm}$ [38]. The reaction mixture, in a total volume of $200 \mu \mathrm{L}$, was comprised of rMnP1 enzyme, sodium malonate $(50 \mathrm{mM}, \mathrm{pH} 4.5)$, and $\mathrm{MnSO}_{4}(100 \mathrm{mM})$. The $\mathrm{Mn}^{3+}$ produced forms a transiently stable complex with malonic acid with a characteristic absorbance at $270 \mathrm{~nm}$. 
Reactions were initiated by the addition of $\mathrm{H}_{2} \mathrm{O}_{2}(100 \mathrm{mM})$. The increase in absorbance was monitored at 5-s intervals during the first $30 \mathrm{~s}$ of reaction. The enzyme activity was defined as follows: one unit (U) of enzyme oxidizes one $\mu \mathrm{mol}$ of guaiacol or $\mathrm{Mn}^{2+}$ per min. Optical densities (ODs) were measured spectrophotometrically at $25{ }^{\circ} \mathrm{C}$ with Varioskan Flash plate reader (Thermo Scientific) equipped with an automated dispensing unit. The enzyme was omitted in the reference assays. Assays were carried out in triplicate.

\section{Conclusions}

The molecular approach carried out in this work for the heterologous expression of a synthetic $\mathrm{MnP1}$ gene in a prokaryote host, allowed for the production of a functional rMnP1 enzyme. This report makes available a novel strategy that hinges on a single-step purification process; such a strategy can be further scaled up for its exploitation in the research field or for biotech purposes. This approach seems promising for the expression and purification of $\mathrm{MnP}$; however, it still needs additional improvements in order to increase its efficiency. Furthermore, structural and kinetic analysis of rMnP1 also needs to be investigated.

Author Contributions: Conceptualization, A.G.-T.; methodology, A.D.L.C.P.-C., J.C.-C., M.d.L.B.-C., R.L.S.-O., S.K.H.-R., N.G.-M., and A.G.-T.; resources, A.D.L.C.P.-C., R.L.S.-O., A.G.-T.; writing-original draft preparation, all authors; writing-review and editing, A.D.L.C.P.-C., N.G.-M., L.R.H.-O., and A.G.-T.; supervision, project administration, and funding acquisition, A.G.-T. All authors have read and agreed to the published version of the manuscript.

Funding: This research was funded by the National Council for Sciences and Technologies from Mexico (CONACyT-Mexico), grant number CB-2011-01-000000000167036. The APC was funded by all authors.

Acknowledgments: The authors acknowledge the National Council of Science and Technology from Mexico (CONACyT) and the Autonomous University of Chihuahua. They also thank David Ortega for his careful reading of the manuscript and helpful comments and suggestions. Angel de la Cruz Pech-Canul was supported by CONACyT through the "Cátedras CONACyT para Jóvenes Investigadores" Programme (Projects \# 609).

Conflicts of Interest: The authors declare no conflict of interest.

\section{References}

1. Wariishi, H.; Valli, K.; Gold, M.H. Manganese(II) oxidation by manganese peroxidase from the basidiomycete Phanerochaete chrysosporium. Kinetic mechanism and role of chelators. J. Biol. Chem. 1992, 267, 23688-23695. [PubMed]

2. Glenn, J.K.; Gold, M.H. Purification and characterization of an extracellular Mn(II)-dependent peroxidase from the lignin-degrading basidiomycete, Phanerochaete chrysosporium. Arch. Biochem. Biophys. 1985, 242, 329-341. [CrossRef]

3. Paszczyński, A.; Huynh, V.-B.; Crawford, R. Enzymatic activities of an extracellular, manganese-dependent peroxidase from Phanerochaete chrysosporium. FEMS Microbiol. Lett. 1985, 29, 37-41. [CrossRef]

4. Glenn, J.K.; Akileswaran, L.; Gold, M.H. Mn(II) oxidation is the principal function of the extracellular Mn-peroxidase from Phanerochaete chrysosporium. Arch. Biochem. Biophys. 1986, 251, 688-696. [CrossRef]

5. Hatakka, A. Biodegradation of Lignin. In Biopolymers Online; Steinbüchel, A., Ed.; John Wiley and Sons: New York, NY, USA, 2005. [CrossRef]

6. Higuchi, T. Look back over the studies of lignin biochemistry. J. Wood Sci. 2006, 52, 2-8. [CrossRef]

7. Martinez, A.T. Molecular biology and structure-function of lignin-degrading heme peroxidases. Enzym. Microb. Technol. 2002, 30, 425-444. [CrossRef]

8. Conesa, A.; Punt, P.J.; van den Hondel, C.A. Fungal peroxidases: Molecular aspects and applications. J. Biotechnol. 2002, 93, 143-158. [CrossRef]

9. Miyazaki, C.; Takahashi, $\mathrm{H}$. Engineering of the $\mathrm{H}_{2} \mathrm{O}_{2}$-binding pocket region of a recombinant manganese peroxidase to be resistant to $\mathrm{H}_{2} \mathrm{O}_{2}$. FEBS Lett. 2001, 509, 111-114. [CrossRef]

10. Reading, N.S.; Aust, S.D. Engineering a disulfide bond in recombinant manganese peroxidase results in increased thermostability. Biotechnol. Prog. 2000, 16, 326-333. [CrossRef] 
11. Ziegenhagen, D.; Hofrichter, M. A simple and rapid method to gain high amounts of manganese peroxidase with immobilized mycelium of the agaric white-rot fungus Clitocybula dusenii. Appl. Microbiol. Biotechnol. 2000, 53, 553-557. [CrossRef]

12. Urek, R.O.; Pazarlioglu, N.K. Enhanced production of manganese peroxidase by Phanerochaete chrysosporium. Braz. Arch. Biol. Technol. 2007, 50, 913-920. [CrossRef]

13. Buswell, J.A.; Mollet, B.; Odier, E. Ligninolytic enzyme production by Phanerochaete chrysosporium under conditions of nitrogen sufficiency. FEMS Microbiol. Lett. 1984, 25, 295-299. [CrossRef]

14. Bono, J.-J.; Goulas, P.; Boe, J.-F.; Portet, N.; Seris, J.-L. Effect of Mn(II) on reactions catalyzed by lignin peroxidase from Phanerochaete chrysosporium. Eur. J. Biochem. 1990, 192, 189-193. [CrossRef] [PubMed]

15. Fujian, X.; Hongzhang, C.; Zuohu, L. Solid-state production of lignin peroxidase (LiP) and manganese peroxidase $(\mathrm{MnP})$ by Phanerochaete chrysosporium using steam-exploded straw as substrate. Bioresour. Technol. 2001, 80, 149-151. [CrossRef]

16. Whitwam, R.E.; Gazarian, I.G.; Tien, M. Expression of fungal Mn peroxidase in E. coli and refolding to yield active enzyme. Biochem. Biophys. Res. Commun. 1995, 216, 1013-1017. [CrossRef]

17. Whitwam, R.; Tien, M. Heterologous expression and reconstitution of fungal Mn peroxidase. Arch. Biochem. Biophys. 1996, 333, 439-446. [CrossRef]

18. Wang, N.; Ren, K.; Jia, R.; Chen, W.; Sun, R. Expression of a fungal manganese peroxidase in Escherichia coli: A comparison between the soluble and refolded enzymes. BMC Biotechnol. 2016, 16, 87. [CrossRef]

19. Pease, E.A.; Aust, S.D.; Tien, M. Heterologous expression of active manganese peroxidase from Phanerochaete chrysosporium using the baculovirus expression system. Biochem. Biophys. Res. Commun. 1991, 179, 897-903. [CrossRef]

20. Jiang, F.; Kongsaeree, P.; Schilke, K.; Lajoie, C.; Kelly, C. Effects of pH and temperature on recombinant manganese peroxidase production and stability. Appl. Biochem. Biotechnol. 2008, 146, 15-27. [CrossRef]

21. Xu, H.; Guo, M.-Y.; Gao, Y.-H.; Bai, X.-H.; Zhou, X.-W. Expression and characteristics of manganese peroxidase from Ganoderma lucidum in Pichia pastoris and its application in the degradation of four dyes and phenol. BMC Biotechnol. 2017, 17, 19. [CrossRef]

22. Hilden, K.; Makela, M.R.; Lundell, T.; Kuuskeri, J.; Chernykh, A.; Golovleva, L.; Archer, D.B.; Hatakka, A. Heterologous expression and structural characterization of two low $\mathrm{pH}$ laccases from a biopulping white-rot fungus Physisporinus rivulosus. Appl. Microbiol. Biotechnol. 2013, 97, 1589-1599. [CrossRef] [PubMed]

23. Gu, L.; Lajoie, C.; Kelly, C. Expression of a Phanerochaete chrysosporium manganese peroxidase gene in the yeast Pichia pastoris. Biotechnol. Prog. 2003, 19, 1403-1409. [CrossRef] [PubMed]

24. Jiang, F.; Kongsaeree, P.; Charron, R.; Lajoie, C.; Xu, H.; Scott, G.; Kelly, C. Production and separation of manganese peroxidase from heme amended yeast cultures. Biotechnol. Bioeng. 2008, 99, 540-549. [CrossRef] [PubMed]

25. Stewart, P.; Whitwam, R.E.; Kersten, P.J.; Cullen, D.; Tien, M. Efficient expression of a Phanerochaete chrysosporium manganese peroxidase gene in Aspergillus oryzae. Appl. Environ. Microbiol. 1996, 62, 860-864. [CrossRef]

26. Cortes-Espinosa, D.V.; Absalon, A.E.; Sanchez, N.; Loera, O.; Rodriguez-Vazquez, R.; Fernandez, F.J. Heterologous expression of manganese peroxidase in Aspergillus niger and its effect on phenanthrene removal from soil. J. Mol. Microbiol. Biotechnol. 2011, 21, 120-129. [CrossRef]

27. Nakano, H.; Yamane, T. Novel techniques using PCR and cell-free protein synthesis systems for combinatorial bioengineering. In Cell-Free Protein Synthesis: Methods and Protocols; Spirin, A.S., Swartz, J.R., Eds.; Wiley-VCH: Weinheim, Germany, 2008; pp. 179-189. [CrossRef]

28. Ninomiya, R.; Zhu, B.; Kojima, T.; Iwasaki, Y.; Nakano, H. Role of disulfide bond isomerase DsbC, calcium ions, and hemin in cell-free protein synthesis of active manganese peroxidase isolated from Phanerochaete chrysosporium. J. Biosci. Bioeng. 2014, 117, 652-657. [CrossRef]

29. Perler, F.B.; Davis, E.O.; Dean, G.E.; Gimble, F.S.; Jack, W.E.; Neff, N.; Noren, C.J.; Thorner, J.; Belfort, M. Protein splicing elements: Inteins and exteins. A definition of terms and recommended nomenclature. Nucleic Acids Res. 1994, 22, 1125-1127. [CrossRef]

30. Singleton, S.F.; Simonette, R.A.; Sharma, N.C.; Roca, A.I. Intein-mediated affinity-fusion purification of the Escherichia coli RecA protein. Protein Expr. Purif. 2002, 26, 476-488. [CrossRef] 
31. Guo, C.; Li, Z.; Shi, Y.; Xu, M.; Wise, J.G.; Trommer, W.E.; Yuan, J. Intein-mediated fusion expression, high efficient refolding, and one-step purification of gelonin toxin. Protein Expr. Purif. 2004, 37, 361-367. [CrossRef]

32. Wu, W.-Y.; Miller, K.D.; Coolbaugh, M.; Wood, D.W. Intein-mediated one-step purification of Escherichia coli secreted human antibody fragments. Protein Expr. Purif. 2011, 76, 221-228. [CrossRef]

33. Carrillo-Campos, J. Expression and Purification of the Manganese Peroxidase 1 from Phanerochaete chrysosporium (Expresión y Purificación de la Manganeso Peroxidasa 1 de Phanerochaete chrysosporium). Master's Thesis, Autonomous University of Chihuahua, Chihuahua, Mexico, 2014. Unpublished.

34. Wariishi, H.; Akileswaran, L.; Gold, M.H. Manganese peroxidase from the basidiomycete Phanerochaete chrysosporium: Spectral characterization of the oxidized states and the catalytic cycle. Biochemistry 1988, 27, 5365-5370. [CrossRef] [PubMed]

35. Alfi, A.; Zhu, B.; Damnjanovic, J.; Kojima, T.; Iwasaki, Y.; Nakano, H. Production of active manganese peroxidase in Escherichia coli by co-expression of chaperones and in vitro maturation by ATP-dependent chaperone release. J. Biosci. Bioeng. 2019, 128, 290-295. [CrossRef] [PubMed]

36. Conesa, A.; van den Hondel, C.A.M.J.J.; Punt, P.J. Studies on the production of fungal peroxidases in Aspergillus niger. Appl. Environ. Microbiol. 2000, 66, 3016-3023. [CrossRef]

37. Paszczyński, A.; Crawford, R.L.; Huynh, V.-B. Manganese peroxidase of Phanerochaete chrysosporium: Purification. In Methods in Enzymology; Academic Press: New York, NY, USA, 1988; Volume 161, pp. $264-270$.

38. Kuan, I.C.; Johnson, K.A.; Tien, M. Kinetic analysis of manganese peroxidase. The reaction with manganese complexes. J. Biol. Chem. 1993, 268, 20064-20070. [PubMed]

(C) 2020 by the authors. Licensee MDPI, Basel, Switzerland. This article is an open access article distributed under the terms and conditions of the Creative Commons Attribution (CC BY) license (http://creativecommons.org/licenses/by/4.0/). 